УДК 655.3.062

\title{
РОЗРОБКА АЛГОРИТМУ \\ АВТОМАТИЗОВАНОГО КОНТРОЛЮ КОЛЬОРОВІДТВОРЕННЯ ДЛЯ ОФСЕТНОГО СПОСОБУ ДРУКУ
}

( В. В. Морфлюк-Щур, аспірантка, НТУУ «КПІ», Київ, Україна

\begin{abstract}
В статье предложен алгоритм автоматизации контроля качества цветопередачи, который базируется на автоматизации процеса измерения и анализа цветовых параметров оттиска - Lab координат контрольных шкал.
\end{abstract}

The article is devoted to the automation algorithm for control over color reproduction quality based on automation of measurement process and analysis of color parameters of the print sheet, namely color chart Lab.

\section{Постановка проблеми}

В останні роки в поліграфічній промисловості все більше уваги приділяється автоматизації всіх виробничих процесів. Впровадження нових підходів та методів у контролі якості поліграфічної продукції вимагає використання нового сучасного обладнання або поліпшення існуючого через автоматизацію окремих ланок.

У цих умовах актуальним $\epsilon$ питання розробки сучасних програмно-технічних засобів автоматизації процесів технологічного контролю якості продукції, розроблення автоматизованих систем контролю кольоровідтворення.

\section{Аналіз попередніх досліджень}

Для вимірювання кольору використовуються два методи: денситометричний і колориметричний. Обидва способи застосовуються у вимірювальних приладах, що реалізовуються як у вигляді ручних індивідуальних пристроїв, так і у формі вимірювальних систем для автоматичного вимірювання по всій площі відбитку. Денситометрами вимірюють оптичну щільність фарбового шару.

Спектрофотометричні і колориметричні вимірювання дають можливість отримувати відбитки, які якісно і кількісно відповідають колірному сприйняттю людиною. Отже, ці вимірювання дають можливість ефективніше здійснювати автоматичне регулювання якості друку в порівнянні 3 виміром лише оптичної щільності. Для автоматизації процесів вимірювання і скорочення часу контролю розроблюються вимірювальні системи.

Більшість сучасних автоматизованих систем пов'язані з денситометричними вімірюваннями. Існують пристрої в яких рухома скануюча денситометрична голівка автоматично вимірює контрольні шкали друкарського аркуша за один прохід. Більш су- 
часні денситометричні системи інтегровані в друкарські машини, і дозволяють оператору 3 пульту керування коригувати товщину фарбового шару на основі вимірювання оптичної густини.

У розпорядженні користувача в даний час $є$ значна кількість ручних моделей приладів для спектрального виміру кольору. Майже всі пристрої дають можливість отримувати не лише спектральних результати, але й значення оптичної густини, що обчислюється на основі спектральних вимірів.

Регулювання процесом друкарської машини можливо проводити 3 допомогою описаних пристроїв для виміру оптичної густини і колориметричних вимірів. Проте для проведення контролю відбиток повинен вийматися друкарем з приймального пристрою друкарської машини і розміщатися на стіл для проглядів з нормованим джерелом освітлення.

При використанні спектральних вимірів кольору після 3-4 регулювань подачі фарби досягається необхідна колориметрична величина на відбитку, а при застосуванні денситометричної вимірювальної техніки це можливо лише на 6-8 кроці вимірів і відповідних корегувань друкарського процесу [1].

Для контролю якості друку, зокрема, при роботі рулонної друкарської машини, застосовуються оптичні прилади візуального контролю. Оптичними приладами контролю можуть бути цифрові фотоапарати, що працюють на матрицях ПЗЗ.
Вони встановлюються безпосередньо на друкарській машині, де при великій роздільній здатності розглядається і аналізується обмежена частина друкарського зображення. Більш досконалі та дорожчі системи дозволяють реєструвати друкарське зображення в цілому.

При використанні швидкодіючих комп'ютерів з значним об'ємом пам'яті навіть при високих швидкостях друку можливо контролювати процес друку накладу в реального масштабі часу. Інформація миттєво обробляється, а оператор отримує необхідне повідомлення, яке дозволяє стежити за станом друкарського процесу, безперервно аналізувати якість продукції та вносити корективи.

Подібні системи технічно складні і ще не в змозі забезпечити оцінку якості, потрібну для автоматичного регулювання суміщення і подачі фарби. Це визначає необхідність розробки спеціальних систем, за допомогою яких була б можливість виконувати (економічно виправдано) виміри кольору в реального масштабу часу 3 необхідною точністю. Це $є$ проблемою, над якою працюють провідні виробники друкарського обладнання [1].

\section{Мета роботи}

Метою даної роботи є розробка алгоритму автоматизованого контролю якості кольоровідтворення для офсетного способу друку на основі застосування спектрофотометричних вимірювань керованих ЕОМ. 


\section{Результати проведених досліджень}

На ринку поліграфічного обладнання існують новітні розробки друкарських машин та поліграфічних комплексів з високим ступенем автоматизації усіх процесів, але й вартість такого обладнання висока. Зважаючи на сьогоднішній економічний стан актуальним $€$ подовження експлуатації існуючого облад- нання, поліпшення складових частин агрегатів, автоматизації вузлів та етапів виробництва.

В представленій роботі пропонується автоматизація процесу контролю за якістю кольоровідтворення, шляхом автоматизації процесу вимірювання і аналізу колірних характеристик друкарських відбитків. Запропонований алгоритм рис. 1, базується на методиці контролю якості кольоровідтворення [3].

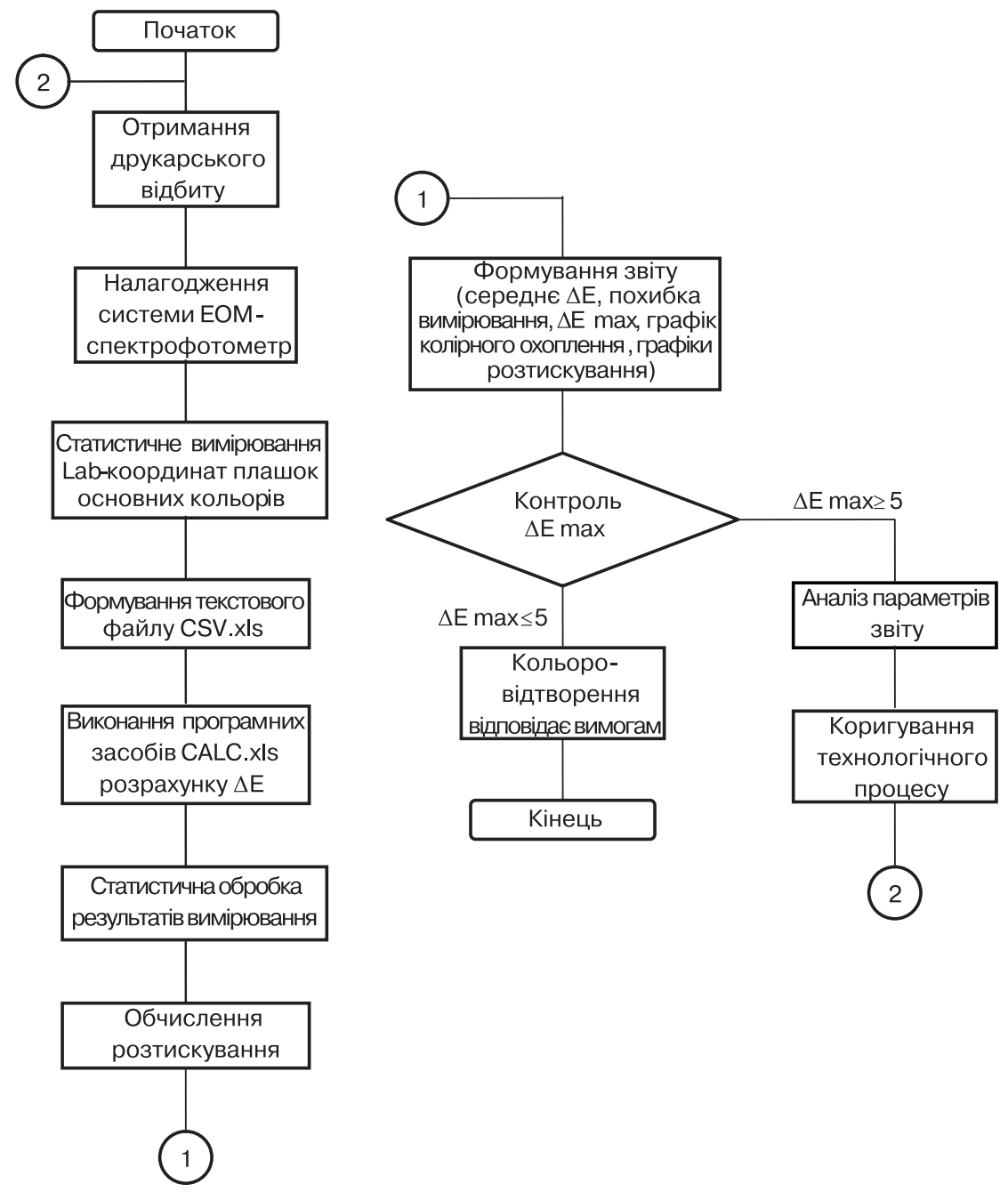

Рис. 1. Алгоритм автоматизації контролю якості кольоровідтворення 
Кольоровідтворення аналізується на друкарському відбитку який отримано або під час налагодження друкарської машини, або під час друку накладу для аналізу стабільності показників. Друкар або спеціаліст виконує технічний контроль друкарського аркушу на столі при нормованому освітленні і нейтральному забарвленні навколишнього простору та за допомогою спектрофотометра під'єднаного до ЕОМ проводить серії вимірів колірних характеристик контрольних плашок. Для отримання, обробки та аналізу вимірів розроблено спеціальне програмне забезпечення, яке базується на використанні наступних програмних засобів: ColorPort, Microsoft Excel [5] та Visual Basic for Application [6]. Статистичні значення Lab координат передаються до EOM у вигляді текстового файлу CSV.xls. За допомогою розроб- лених програмних засобів CALC.xIs виконується статистична обробка вимірів, розрахунок показника $\Delta \mathrm{E} 2000$, значення розтискування друкарської фарби. Результати обчислень подаються у вигляді звіту, в якому представлено графік колірного охоплення друкарського процесу та графіки розтискування для кожної з чотирьох основних фабр. Згідно рекомендацій міжнародного стандарту ISO 12647-2 [2] якість кольровідтворення визначається при показнику $\Delta \mathrm{E}[4]$ в межах від 0 до 5 одиниць рис. 2:

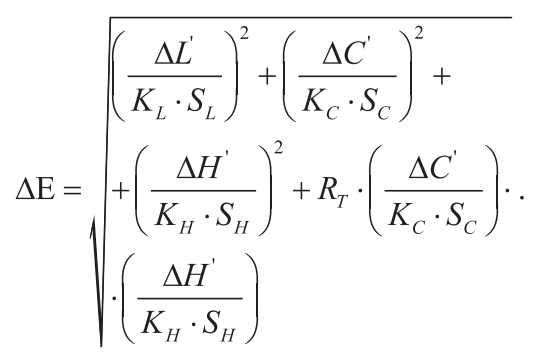

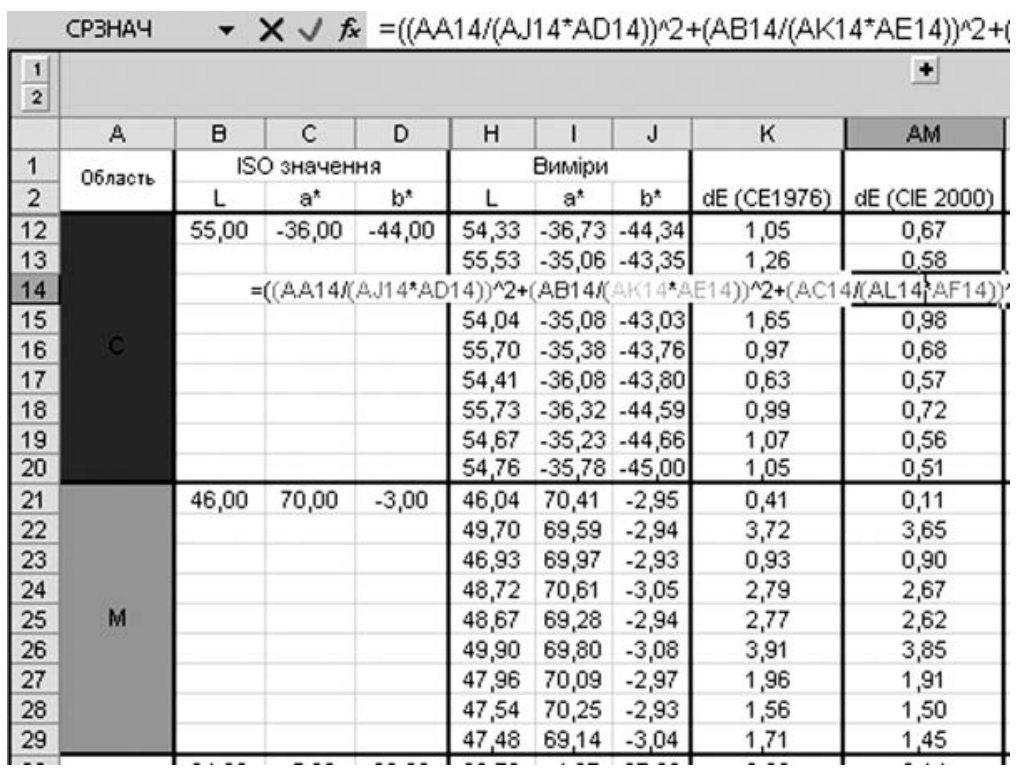

Рис. 2. Приклад розрахунку показника $\Delta \mathrm{E}$ в програмі Microsoft Excel 
При задовільних результатах кольоровідтворення до технологічної карти замовлення додається звіт, що є об'єктивним підтвердженням якості кольоровідтворення у відповідності до міжнарождного стандарту ISO 12647-2.

При відхиленні показника $\Delta \mathrm{E}$ від рекомендованих норм необхідно проводити коригування технологічного процесу, наприклад контроль подачі фарби (оптична густина, розтискування), перевірка відповідності обраного паперу і фарби поставленим вимогам якості та інше.

\section{Висновки}

На основі аналізу проведених досліджень запропоновано алгоритм автоматизації контролю якості кольоровідтворення. В основу алгоритму покладено автоматизацію процесів вимірювання та програмного аналізу колірних характеристик відбитків. Запропонований алгоритм дозволяє автоматизувати технологічний контроль, налагоджування устаткування, прийняття рішення щодо якості тиражу, а в разі невідповідності нормам своєчасно та обґрунтовано корегувати технологічний процес та зменшувати брак.

1. Киппхан Г. Энциклопедия по печатным средствам информации / Г. Киппхан. - М. : МГУП, 2003. - С. 1280. 2. дСтУ ISO 12647-2:2005. Поліграфія. Керування процесами виготовляння растрових кольороподілених фотоформ, пробних і тиражних відбитків. Частина 2. Процеси офсетного плоского друкування. 3. Морфлюк-Щур В. В. Розробка методики об'єктивного контролю кольоровідтворення для офсетного способу друку / В. В. Морфлюк-Щур // Технологія і техніка друкарства. - 2010. - № 4. С. 46-50. 4. [Електронний ресурс]. - Режим доступу : http://www. brucelindbloom.com : Useful Color Equations: mathematical equations for converting among various colorimetric representations. 5. Курбатова Е. А. Microsoft Office Excel 2010. Самоучитель / Е. А. Курбатова. - К. : Диалектика, Вильямс, 2010. - 416 с. 6. Кузьменко В. Г. VВА / В. Г. Кузьменко. - М. : Бином-Пресс, 2008. - 624 с. 